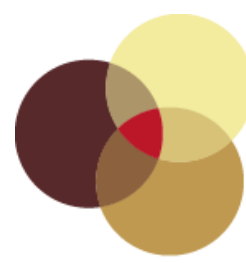

contennporaneity

Vol 7, No 1 (2018) ｜ＩSSN 2153-5914 (online) ｜ＤOI 10.5195/contemp/2018.265

http://contemporaneity.pitt.edu

\title{
The Invention of Race in the Middle Ages Geraldine Heng
}

Jacqueline Lombard

\section{Book Review}

Geraldine Heng, The Invention of Race in the Middle Ages. New York: Cambridge University Press, 2018. 504 pp.; 10 ills. Hardcover, £34.99 (9781108422789)

\section{About the Author}

Jacqueline Lombard is a PhD candidate in the history of art and architecture at the University of Pittsburgh, where she also earned her M.A, in 2017. Prior to coming to Pitt she earned her B.A. in studio art and medieval and Renaissance Studies at Carleton College. She specializes in medieval art history, with a particular focus on the history of art objects as products or conduits of cross-cultural exchange across medieval Europe, the Middle East, and Northern and Eastern Africa. Her research explores premodern conceptions of ethnic and racial identity, and seeks to understand how medieval peoples engaged with art objects to articulate and understand their own identities and spaces within their global networks. 


\section{The Invention of Race in the Middle Ages}

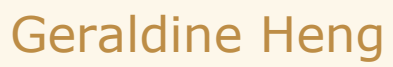

Jacqueline Lombard
Straddling the complicated line between medieval studies and critical race theory, The Invention of Race in the Middle Ages is a comprehensive volume that will change the ways in which medieval history is understood. Operating between two fields that have historically taken little interest in each other, Geraldine Heng addresses race alongside power, empire, gender, religion, culture, literature, and art with tremendous insight built on meticulous research. She compels readers to consider how race shaped medieval European societies and worldviews, and how its roots can be detected far earlier than canonically assumed.

Heng's attention to particularities in The Invention of Race in the Middle Ages is praiseworthy, and more remarkable is her ability to weave so many seemingly disparate case studies into one comprehensive analysis. The Invention of Race stands upon the last few decades of foundational works on medieval race, which consist largely of a diverse array of individual case studies. Heng lays out the recent historiography of both medieval studies and critical race theory in her first chapter, where she also offers a trans-historical definition of race that serves as the foundation for the chapters to come. Throughout the book, Heng presents a strong argument for a comparative approach to the study of historical race as she explicates a wide variety of source materials to illuminate previously undetected patterns of race-making. Heng repeatedly demonstrates that each medieval source has its own agenda and its own stake within its own context and audience. When studied together, however, each narrative offers more insight into the trans-cultural development of race.

The second and third chapters explore how race could be built upon religious difference in the medieval world, and how religious race was frequently blurred with ideologies about blood and genealogy-based race that could not be altered, even by conversion. Chapter 2 explores chronicles, charters, and statutes that pertain to the legal treatment and subsequent persecution of Jews in medieval England. Heng compares these social laws to later literary works produced in England after the expulsion of 1290 in order to unpack their implications within the English Christian imagination. Chapter 3 turns to the so-called Saracens through analysis of crusade accounts, trade contracts, and epic poetry to explore how Europeans engaged with, feared, or fantasized about their Muslims neighbors, and how European ideas of race could be quite fluid depending on the political or economic situation at hand.

In these opening chapters, and in those that follow, it becomes increasingly clear that the circumstances that give way to medieval ideas of race often differ from those of the modern world. Medieval ideas of race tend to be more nuanced, and not yet systematized. Heng skillfully navigates and unpacks these differences. In Chapter 4, she turns to the question of color-based race-perhaps the most resonant with modern readers-to explore the distinctly medieval manifestations of color-based racial ideologies. In this chapter, Heng parses the multifaceted meanings of blackness in medieval European thought, as a concept distinct but not exclusive from African identity or the actual quality of having black skin. Figures such as Moriaen, Saint Maurice, Abba Moses, and the Queen of Sheba are brought together with works including the King of Tars, Parzival, and Albertus Magnus's Quaestiones super De animalibus to explore how artistic and philosophical explorations of the meaning of blackness shaped white European perceptions toward black African people. Heng pays careful attention to the developing concept of whiteness as well, and how medieval terminology and thought came to influence color-based racial ideologies as they would eventually exist in the modern world.

The last section of the book addresses the nature of globalism in the twelfth through fifteenth centuries and elucidates how Europeans conceptualized the more geographically distant peoples they encountered outside the Abrahamic faiths. Chapter 5 considers the 
archeological remnants of Norse contact in North America alongside contemporary saga narratives, arguing that many of the mythical creatures and encounters explored in these stories were based upon their understanding of Native Americans. Chapter 6 considers accounts written by Europeans who encountered the Mongol Court, and Chapter 7 traces the woefully understudied arrival of the Romani in Europe by studying their depictions within Persian and European romances, chronicles, and legal correspondence. In these last chapters, Heng's research acumen shines: she foregrounds how Europeans perceived the Native Americans, Mongols, and Romani, which she astutely follows with insights into how these groups perceived themselves. Heng thus offers a refreshing emphasis on the identities and cultural practices of the groups in question not simply as racialized subjects, but for their own historical merits as well.

At the center of Heng's work is the question of how to address race in these diverse but intersecting contexts and what race represents through a trans-historical lens. She ably demonstrates that race, as a social force enacted by groups of people to categorize human beings via differences believed to be fundamental and immutable, was indeed developing in the Middle Ages and must be studied as such. This timely argument comes after multiple decades of debate among medievalists about whether the term race can be appropriately used in medieval studies, or if such a question has any purchase in the first place. Terms such as "difference," "xenophobia," "alterity," and "otherness" have been championed as more suitable alternatives as medieval peoples themselves never used the word race. By adhering to the methodological lens of critical race theory, Heng persuasively shows how more ambiguous terms such as difference or otherness can quickly lose their potency, and that race, with all of its larger implications, presents the only appropriate term to use. The debates raised and addressed in this work will challenge scholars to radically rethink how they approach the social histories with which they work, and for scholars who consider social context to be an essential aspect of their research, The Invention of Race is a must-read.

(c) $\mathbf{c}$ EY New articles in this journal are licensed under a Creative Commons Attribution 4.0 United States License.

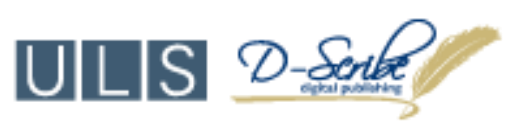

This journal is operated by the University Library System of the University of Pittsburgh as part of its D-Scribe Digital Publishing Program, and is co-sponsored by the University of Pittsburgh Press. 